\title{
PERAN GURU PENDIDIKAN AGAMA ISLAM DALAM MENGATASI PERILAKU NEGATIF SISWA MTS PUI SEGERAN INDRAMAYU
}

\author{
Oleh: \\ Asep Kurniawan \\ Dosen Manajemen Pendidikan Islam IAIN Syekh Nurjati Cirebon \\ asep.kurniawan@syekhnurjati.ac.id
}

\begin{abstract}
Students of Madrasah Tsanawiyah PUI Segeran Indramayu had negative behavior. This was in stark contrast to the views of the surrounding community. They thought that students who study in religious education institutions, such as Madrasah Tsanawiyah, had better behavior than students who study in secondary schools. It was because Madrasah Tsanawiyah is an Islamic school. The purpose of the study was to reveal in depth about the role of Islamic Education teachers in overcoming students' negative behavior. This study used a qualitative approach. The research findings showed that students' negative behavior are lighting firecrackers in class, not wearing uniforms, not working on teachers' assignments, chatting and joking in learning, drawing motorcycle gang names in books, singing persib songs, making and playing paper airplane. This behavior was influenced by internal and external factors. In this case, Islamic education teachers carried out preventive actions, namely: congregational prayers, commemoration of Islamic holidays, Pesantren Ramadan, Islamic education teachers' exemplary, empowering extra organizations, mentoring, reminding, advising, and inviting dialogue, weekly religious studies. Repressive measures were to provide penalties toward educating not oppressive, and give more assignments than other students. Curative actions, namely: (1) general actions, they included: (a) Advice and reprimand with a religious approach. (b) Provide reasonable special attention to problematic students. (c) Cooperate with parents of problematic students in overcoming their negative behavior. (2) (2) Special actions through a case-by-case individual approach.
\end{abstract}

Keywords: Environment, Modeling, Attention, Affection, Religious

\section{A. Latar Belakang}

Pendidikan nasional berfungsi mengembangkan kemampuan dan membentuk watak serta peradaban bangsa yang bermartabat dalam rangka mencerdaskan kehidupan bangsa, bertujuan untuk berkembangnya potensi peserta didik agar menjadi manusia yang beriman dan bertakwa kepada Tuhan Yang Maha Esa, berakhlak mulia, sehat, berilmu, cakap, kreatif, 
mandiri dan menjadi warga negara yang demokratis dan bertanggungjawab (Undang-undang No. 20 Tahun 2003 pasal 3).

Dari tujuan yang sudah dirumuskan tersebut salah satunya terdapat pembentukan bangsa yang berakhlak mulia. Berbicara mengenai akhlak, erat hubungannya dengan tingkahlaku yang dimiliki seseorang. Jika tingkahlaku yang ditunjukkan seseorang itu baik maka orang tersebut dapat disebut memiliki akhlak yang baik. Sedangkan apabila perilaku yang ditunjukkan seseorang itu buruk maka orang tersebut tidak berakhlak mulia. Setiap individu mempunyai beragam watak, sifat dan sikap yang berbeda. Demikian pula dengan siswa mempunyai keunikan dan kekhasan masing-masing pada dirinya. Karakteristik individu (siswa) didapatkan dari faktor bawaan dan faktor dari pengaruh lingkungan (Marsudi, 2003: 1). 1

Karakteristik bawaan adalah karakteristik individu yang didapatkan melalui pewarisan dari pihak orang tuanya. Sedangkan karakteristik dari faktor lingkungan didapatkan dari pengaruh lingkungan sosial, psikis, fisik, alam sekitar dan agama. ${ }^{2}$ Begitu erat hubungannya perilaku siswa dalam merealisasikan bangsa yang berakhlak mulia. Madrasah Tsanawiyah sebagai penyelenggara pendidikan menjadi pondasi penting untuk mewujudkan hal tersebut. Jenjang sekolah menengah pertama adalah jenjang yang sangat kompleks permasalahannya. Di jenjang tersebut, peserta didik mengalami transisi perilaku dari masa kanak-kanak menjadi peserta didik sekolah menengah (remaja). Pada jenjang sekolah menengah pertama, anak belajar banyak hal di sekolah. Dari hasil pembelajarannya, siswa mulai menyadari perbedaan atau kesamaan dirinya dengan teman-temannya. Siswapun belajar mengenai banyak norma dan nilai yang dijadikan acuan tindakan dan tingkahlaku moral siswa.

Elizabeth B. Hurlock mengatakan bahwa akhir masa kanak-kanak sering disebut sebagai "usia kelompok" sebab ditandai dengan adanya minat terhadap kegiatan teman-teman

\footnotetext{
${ }^{1}$ Marsudi, Saring, Layanan Bimbingan Belajar di Sekolah (Surakarta: Muhammadiyah University Press, 2003), 1.

${ }^{2}$ Syamsu Yusuf LN, Psikologi Perkembangan Anak dan Remaja (Bandung: Remaja Rosdakarya, 2009), 31.
}

Jurnal Pendidikan Agama Islam

IAIN Syekh Nurjati Cirebon 
dan meningkatnya keinginan yang kuat untuk diterima sebagai anggota suatu kelompok, dan merasa tidak puas jika tidak bersama teman-temannya. ${ }^{3}$

Tingkahlaku menjadi amat krusial sekali dalam kehidupan bermasyarakat, sebab masing-masing kegiatan interaksi sosial yang kita lakukan tidak terlepas dari perilaku individu tersebut dalam berinteraksi. Setiap siswa mengalami tahap-tahap perkembangan. Tahap-tahap perkembangan anak secara umum sama. Pada setiap perkembangan, setiap siswa dituntut untuk bisa bertindak atau melakukan hal-hal (perilaku) yang menjadi tugas perkembangannya dengan baik.

Apabila siswa bisa melaksanakan tugas perilaku pada masa perkembangannya dengan baik, siswa tersebut dikatakan berperilaku normal. Masalah muncul apabila siswa berperilaku tidak sesuai dengan tugas perkembangannya. Siswa yang berperilaku di luar perilaku normal disebut siswa yang berperilaku menyimpang (student deviant behavior).

Perilaku siswa yang menyimpang, mempunyai hubungan dengan penyesuaian siswa tersebut dengan lingkungannya. Hurlock mengatakan bahwa perilaku siswa bermasalah atau menyimpang ini muncul karena penyesuaian yang harus dilakukan siswa terhadap tuntutan dan kondisi lingkungan yang baru. Berarti semakin besar tuntutan dan perubahan semakin besar pula masalah penyesuaian yang dihadapi siswa tersebut. ${ }^{4}$

Perilaku menyimpang adalah suatu persoalan yang harus menjadi kepedulian guru, bukan semata-mata perilaku itu destruktif atau mengganggu proses pembelajaran, melainkan suatu bentuk perilaku agresif atau pasif yang dapat menimbulkan kesulitan dalam bekerja sama dengan teman, yang merupakan perilaku yang dapat menimbulkan masalah belajar siswa dan hal itu termasuk perilaku bermasalah. ${ }^{5}$ Guru perlu memahami perilaku bermasalah ini sebab siswa yang bermasalah biasanya tampak di dalam kelas dan bahkan dia menampakkan perilaku bermasalah itu di dalam keseluruhan interaksi dengan lingkungannya.

\footnotetext{
${ }^{3}$ Elizabeth. B Hurlock, Perkembangan Anak Jilid 1 (Jakarta: Erlangga, 2004), 155-156.

${ }^{4}$ Elizabeth. B Hurlock, Perkembangan Anak Jilid 1 ........., 39.

${ }^{5}$ Abu Darwis, Perilaku Menyimpang Murid SD (Jakarta: Departemen Pendidikan Nasional Direktorat Jendral Pendidikan Tinggi Direktorat Ketenagaan, 2006), 43.
}

Jurnal Pendidikan Agama Islam

IAIN Syekh Nurjati Cirebon 
Walaupun gejala perilaku bermasalah di sekolah itu mungkin hanya tampak pada sebagian siswa, pada dasarnya setiap siswa memiliki masalah-masalah emosional dan penyesuaian sosial. Masalah itu tidak selamanya menimbulkan perilaku bermasalah atau menyimpang yang kronis. ${ }^{6}$

Pada saat bersosialisasi maka yang ditunjukkannya adalah perilaku sosial. Perilaku manusia merupakan respons dari stimulus, namun dalam diri individu itu ada kemampuan untuk menentukan perilaku yang diambilnya. Ini berarti individu dalam keadaan aktif dalam menentukan perilaku yang diambilnya. Hubungan antara stimulus dan respon ini tidak berlangsung secara otomatis tetapi individu mengambil peranan dalam menentukan perilakunya. Manusia dalam hal ini berarti memiliki kemampuan untuk menentukan perilakunya, dan tentunya penentuan itu menggunakan akal manusia yang merupakan hadiah terbesar dari Tuhan. Setelah manusia mendapatkan stimulus seperti yang dikatakan tadi pada saat itu juga manusia berhak untuk menentukan perilakunya. Dan itu semua tentunya dilandaskan dengan kesadaran, karena ketika orang tersebut melakukan sesuatu tanpa dilandasi dengan adanya kesadaran atau bisa dikatakan hilang kesadaranya, maka hal tersebut tidak bisa dikatakan sebagai perilaku.

Madrasah Tsanawiyah merupakan lembaga pendidikan menengah yang diselenggarakan untuk mengembangkan sikap, kemampuan dan keterampilan dasar yang diperlukan siswa untuk hidup di masyarakat. Siswa sekolah ini pada umumnya berusia 13 sampai 15 tahun. Ada tiga ciri yang menonjol pada masa ini, yaitu dorongan yang besar untuk berhubungan dengan kelompok sebaya, dorongan ingin tahu tentang dunia sekitarnya, dan perkembangan fisik.

Dari pendapat di atas menunjukkan bahwa anak pada usia 13 sampai 15 tahun dalam perkembangan memasuki usia sekolah dan pada masa ini, siswa memiliki dorongan yang kuat untuk berhubungan dengan kelompok sebayanya, ingin tahu tentang dunia sekitarnya, dan menyenangi permainan yang mengarah pada dunia pekerjaan.

\footnotetext{
${ }^{6}$ Abu Darwis, Perilaku Menyimpang Murid SD, .........., 44.

Jurnal Pendidikan Agama Islam IAIN Syekh Nurjati Cirebon
} 
Berdasarkan hasil observasi yang peneliti lakukan pada hari jum'at tanggal 13-16 Oktober 2018 yang dilakukan di Madrasah Tsanawiyah (MTs) PUI Segeran Indramayu, peneliti menemukan terdapat beragam perilaku sosial siswa, yang mana bentuk perilaku negatif siswa lebih menonjol sekali dibandingkan dengan perilaku yang mencerminkan kepribadian yang baik. Hal ini sangat kontras sekali dengan pandangan masyarakat sekitar bahwa siswa yang bersekolah di lembaga pendidikan keagamaan seperti Madrasah Tsanawiyah akan memiliki perilaku dan etika yang jauh lebih baik dibandingkan dengan siswa yang sekolah di sekolah menengah pada umum, hal tersebut dikarenakan Madrasah Tsanawiyah merupakan sebuah sekolah yang berlabel Islam, sebuah sekolah yang dikenal kental akan nuansa keagamaannya karena Madrasah Tsanawiyah adalah sebuah madrasah yang mempunyai nilai lebih dalam bidang pelajaran keagamaan dibandingkan dengan Sekolah Menengah Pertama, sehingga pembentukan pendidikan karakter siswa di Madrasah Tsanawiyah lebih intensif. Namun dalam realita yang peneliti temukan di MTs PUI Segeran ini justru sebaliknya, yaitu banyak sekali ditemukan perilaku negatif yang dilakukan oleh siswa. Dalam hal ini guru dan pihak sekolah di MTs PUI Segeran Indramayu selaku pihak yang berfungsi menggerakkan jalannya proses pendidikan perlu memahami perilaku bermasalah ini, sebab anak yang bermasalah biasanya tampak di dalam kelas dan bahkan dia menampakkan perilaku bermasalah itu di dalam keseluruhan interaksi dengan lingkungannya.

\section{B. Tinjauan Teori}

1. Pendidikan Agama Islam untuk Mengatasi Perilaku Negatif Siswa

Mengatasi, menanggulangi dan mencegah perilaku negatif siswa sudah banyak dilakukan baik perorangan ataupun kelompok. Kesemuanya mempunyai harapan dan tujuan yang sama, yakni menjadikan peserta didik dapat menerima kondisi dirinya dan lingkungan dengan wajar. Zakiah Darajat menawarkan beberapa solusi mengatasi perilaku negatif siswa yaitu: 
a. Pendidikan agama mesti dilakukan pertama kali di keluarga, sejak anak masih kecil. Yang terpenting ialah jiwa percaya kepada Tuhan, membiasakan mentaati dan menjaga kaidah-kaidah dan nilai-nilai yang ditentukan oleh ajaran agama.

b. Orang tua mesti memahami dasar-dasar pendidikan, pendidikan dan perlakuan yang diterima oleh anak sejak kecil adalah suatu pokok dari kenakalan anak, maka orang tua mesti mengetahui bentuk-bentuk dasar pengetahuan yang setidaknya mengenai jiwa anak dan pokok pendidikan yang mesti dilakukan dalam menghadapi beragam sifat anak.

c. Penggunaan waktu luang dengan baik, cara pengisian waktu luang dengan tidak membiarkan anak mencari jalan sendiri. Khususnya anak yang sedang menginjak masa remaja, sebab pada masa ini anak sedang menghadapi banyak perubahan dan banyak menemui permasalahan pribadi. Jika tidak pandai menggunakan waktu luang, mungkin akan tenggelam memikirkan diri sendiri dan menjadi suka melamun.

d. Memberikan bimbingan dan penyuluhan di sekolah ini dalam rangka memberikan solusi bagi perilaku negatif siswa.

e. Memberikan pemahaman dan pengalaman ajaran agama.

f. Memfilter buku-buku cerita, film-film dan lain-lain, karena perilaku negatif siswa tidak bisa dilepaskan dari pendidikan dan perlakuan yang diterimanya dari orang tua, sekolah dan masyarakat. ${ }^{7}$

Dewasa ini bentuk perilaku negatif siswa tidak lagi dikatagorikan kenakalan biasa, namun telah cenderung kepada tindakan kriminal yang cukup memperihatinkan dan meresahkan masyarakat. Peran guru Pendidikan Agama Islam dalam mengatasi perilaku negatif peserta didik dilaksanakan secara pencegahan (prefentif), refresif dan secara penyembuhan (kuratif) yang dapat dilakukan oleh guru Pendidikan Agama Islam. Oleh karena itu merupakan suatu kewajiban bersama untuk mengatasi terhadap terjadinya perilaku negatif peserta didik, baik mengatasi secara preventif, represif ataupun kuratif.

\footnotetext{
${ }^{7}$ Zakiyah Daradjat, Remaja Harapan dan Tantangan (Jakarta: Ruhama, 1995), 121-125.

Jurnal Pendidikan Agama Islam IAIN Syekh Nurjati Cirebon
} 


\section{Perilaku Sosial Siswa}

Perilaku sosial seseorang merupakan sifat relatif untuk menanggapi orang lain dengan cara-cara yang berbeda-beda. Misalnya dalam melakukan kerja sama, ada orang yang melakukannya dengan tekun, sabar dan selalu mementingkan kepentingan bersama diatas kepentingan pribadinya. Sementara di pihak lain, ada orang yang bermalas-malasan, tidak sabaran dan hanya ingin mencari untung sendiri.

Pembentukan perilaku sosial seseorang dipengaruhi oleh berbagai faktor baik yang bersifat internal maupun yang bersifat eksternal. Pada aspek eksternal situasi sosial memegang pernana yang cukup penting. Situasi sosial diartikan sebagai tiap-tiap situasi di mana terdapat saling hubungan antara manusia yang satu dengan yang lain. ${ }^{8}$

Berbagai bentuk dan jenis perilaku sosial seseorang pada dasarnya merupakan karakter atau ciri kepribadian yang dapat teramati ketika seseorang berinteraksi dengan orang lain. Seperti dalam kehidupan berkelompok, kecenderungan perilaku sosial seseorang yang menjadi anggota kelompok akan terlihat jelas diantara anggota kelompok yang lainnya. Perilaku sosial dapat dilihat melalui sifat-sifat dan pola respon antar pribadi, yaitu:

\section{a. Kecenderugan Perilaku Peran}

1) Sifat pemberani dan pengecut secara sosial

Orang yang memiliki sifat pemberani secara sosial, biasanya dia suka mempertahankan dan membela haknya, tidak malu-malu atau tidak segan melakukan sesuatu perbuatan yang sesuai norma di masyarakat dalam mengedepankan kepentingan diri sendiri sekuat tenaga. Sedangkan sifat pengecut menunjukkan perilaku atau keadaan sebaliknya, seperti kurang suka mempertahankan haknya, malu dan segan berbuat untuk mengedepankan kepentingannya.

\footnotetext{
${ }^{8}$ W.A. Gerungan, Psikologi Sosial (Bandung: PT. al-Maarif, 1978), 77.

Jurnal Pendidikan Agama Islam IAIN Syekh Nurjati Cirebon
} 
2) Sifat berkuasa dan sifat patuh

Orang yang memiliki sifat sok berkuasa dalam perilaku sosial biasanya ditunjukkan oleh perilaku seperti bertindak tegas, berorientasi kepada kekuatan, percaya diri, berkemauan keras, suka memberi perintah dan memimpin langsung. Sedangkan sifat yang patuh atau penyerah menunjukkan perilaku sosial yang sebaliknya, misalnya kurang tegas dalam bertindak, tidak suka memberi perintah dan tidak berorientasi kepada kekuatan dan kekerasan.

3) Sifat inisiatif secara sosial dan pasif

Orang yang memiliki sifat inisiatif biasanya suka mengorganisasi kelompok, tidak suka mempersoalkan latar belakang, suka memberi masukan atau saran-saran dalam berbagai pertemuan dan biasanya suka mengambil alih kepemimpinan. Sedangkan sifat orang yang pasif secara sosial ditunjukkan oleh perilaku yang bertentangan dengan sifat orang yang aktif, misalnya perilakunya yang dominan diam, kurang berinisiatif, tidak suka memberi saran atau masukan.

4) Sifat mandiri dan tergantung

Orang yang memiliki sifat mandiri biasanya membuat segala sesuatunya dilakukan oleh dirinya sendiri, seperti membuat rencana sendiri, melakukan sesuatu dengan cara-cara sendiri, tidak suak berusaha mencari nasihat atau dukungan dari orang lain, dan secara emosiaonal cukup stabil. Sedangkan sifat orang yang ketergantungan cenderung menunjukkan perilaku sosial sebaliknya dari sifat orang mandiri, misalnya membuat rencana dan melakukan segala sesuatu harus selalu mendapat saran dan dukungan orang lain, dan keadaan emosionalnya relatif labil.

b. Kecenderungan perilaku dalam hubungan sosial

1) Dapat diterima atau ditolak oleh orang lain

Orang yang memiliki sifat dapat diterima oleh orang lain biasanya tidak berprasangka buruk terhadap orang lain, loyal, dipercaya, pemaaf dan tulus menghargai kelebihan orang lain. Sementara sifat orang yang ditolak biasanya suka mencari kesalahan dan tidak mengakui kelebihan orang lain. 
2) Suka bergaul dan tidak suka bergaul

Orang yang suka bergaul biasanya memiliki hubungan sosial yang baik, senang bersama dengan yang lain dan senang bepergian. Sedangkan orang yang tidak suka bergaul menunjukkan sifat dan perilaku yang sebaliknya.

3) Sifat ramah dan tidak ramah

Orang yang ramah biasanya periang, hangat, terbuka, mudah didekati orang dan suka bersosialisasi. Sedang orang yang tidak ramah cenderung bersifat sebaliknya.

4) Simpatik atau tidak simpatik

Orang yang memiliki sifat simpatik biasanya peduli terhadap perasaan dan keinginan orang lain, murah hati dan suka membela orang tertindas. Sedangkan orang yang tidak simpatik menunjukkan sifat-sifat yang sebaliknya.

c. Kecenderungan perilaku ekspresif

1) Sifat suka bersaing (tidak kooperatif) dan tidak suka bersaing (suka bekerjasama) Orang yang suka bersaing biasanya menganggap hubungan sosial sebagai perlombaan, lawan adalah saingan yang harus dikalahkan, memperkaya diri sendiri. Sedangkan orang yang tidak suka bersaing menunjukkan sifat-sifat yang sebaliknya

2) Sifat agresif dan tidak agresif

Orang yang agresif biasanya suka menyerang orang lain baik langsung ataupun tidak langsung, pendendam, menentang atau tidak patuh pada penguasa, suka bertengkar dan suka menyangkal. Sifat orang yang tidak agresif menunjukkan perilaku yang sebaliknya.

3) Sifat kalem atau tenang secara social

Orang yang kalem biasanya tidak nyaman jika berbeda dengan orang lain, mengalami kegugupan, malu, ragu-ragu, dan merasa terganggu jika ditonton orang.

4) Sifat suka pamer atau menonjolkan diri

Orang yang suka pamer biasanya berperilaku berlebihan, suka mencari pengakuan, berperilaku aneh untuk mencari perhatian orang lain. 
Perilaku sosial individu dilihat dari kecenderungan peranan (role disposition) dapat dikatakan memadai, manakala menunjukkan ciri-ciri respons interpersonal sebagai berikut: (1) yakin akan kemampuannya dalam bergaul secara sosial; (2) memiliki pengaruh yang kuat terhadap teman sebaya; (3) mampu memimpin teman-teman dalam kelompok; dan (4) tidak mudah terpengaruh orang lain dalam bergaul. Sebaliknya, perilaku sosial individu dikatakan kurang atau tidak memadai manakala menunjukkan ciri-ciri respons interpersonal sebagai berikut: (1) kurang mampu bergaul secara sosial; (2) mudah menyerah dan tunduk pada perlakuan orang lain; (3) pasif dalam mengelola kelompok; dan (4) tergantung kepada orang lain bila akan melakukan suatu tindakan.

Kecenderungan-kecenderungan tersebut merupakan hasil dan pengaruh dari faktor konstitutsional, pertumbuhan dan perkembangan individu dalam lingkungan sosial tertentu dan pengalaman kegagalan dan keberhasilan berperilaku pada masa lampau

\section{Metode Penelitian}

Jenis penelitian ini adalah penelitian kualitatif deskriptif dari Juni sampai Desember 2018. Objek penelitiannya yaitu siswa-siswa Madrasah Tsanawiyah PUI Segeran, Desa Segeran Kidul Kecamatan Juntinyuat Kabupaten Indramayu, Jawa Barat. Analisis yang digunakan dalam penelitian ini adalah deskriptif fenomenologis, yaitu mendeskripsikan temuan-temuan yang ada di lapangan untuk mendapatkan gambaran yang obyektif tentang suatu kasus yang diteliti. Dalam penelitian ini peneliti menggunakan rancangan studi kasus etnografi yang melibatkan observasi partsipatif, wawancara, dan dokumentasi dalam pengumpulan datanya. Alasan penggunaan racangan studi kasus etnografi di gunakan dalam penelitian ini karena untuk memudahkan peneliti dalam menemukan hasil penelitian terkait dengan judul yang di ambil oleh peneliti. Berdasarkan studi awal yang dilakukan oleh peneliti terkait dengan permasalahan yang diangkat dalam judul ini bahwasanya penelitian ini membutuhkan informasi yang holistik dan secara mendalam sehingga penggunaan studi kasus etnografi ini sangat sesuai untuk mendukung hasil penelitian 


\section{Temuan dan Pembahasan Penelitian}

\section{Perilaku Negati Siswa}

Bentuk perilaku negatif siswa-siswa MTs PUI Segeran Indramayu yang kami temukan selama proses penelitian beragam sekali. Kami menemukan banyak perilaku negatif siswa terlihat sangat kentara ketika pada saat proses pembelajaran berlangsung. Di sana sangat jelas sekali dalam pengamatan kami aktivitas dalam kegiatan pembelajaran yang tidak kondusif disebabkan perilaku negatif siswa yang menghambat pembelajaran. Adapun bentuk perilaku negatif yang kami temukan pada siswa-siswa MTs PUI Segeran yaitu:

a. Menyalakan Petasan di dalam Kelas

Hasil observasi peneliti terkait siswa yang menyalakan petasan ini terlihat pada saat jam istirahat sudah selesai yaitu pukul 10.30 WIB dan semua murid kelas 8 sudah berada di dalam kelas menunggu guru mata pelajaran Budi Pekerti masuk untuk mengajar. Siswa yang menyalakan petasan adalah seorang anak laki-laki yang tempat duduknya berada di paling belakang dan di pojok kelas. Petasan tersebut tidak berbunyi namun asap berwarna putih pekat dan bau khas dari petasan terlihat dan sangat terasa di ruangan kelas 8 tersebut. Peneliti juga melihat ada korek api sebagai alat untuk menyalakan petasan. Kejadian itu di lakukan sebelum proses pembelajaran dimulai ketika pada mata pelajaran Budi Pekerti sebelum guru tersebut datang. Diketahui dari hasil wawancara kami dengan siswa yang menyalakan petasan tersebut bahwa siswa yang menyalakan petasan bernama MAA yang sering dipanggil dengan sebutan Api oleh teman sekelasnya, siswa tersebut berumur 12 tahun yang lahir pada tanggal 01 juni 2005. Kami kesulitan memperoleh informasi terkait alasan mengapa ia membawa dan menyalakan petasan tersebut di dalam kelas karena ketika dilakukan wawancara ia tidak menjawab pertanyaan dari kami, ia terdiam tidak mengatakan apapun hanya menunjukkan ekspresi senyum, tangannya bergerak aktif memukul tas yang ada di atas meja sambil tersipu malu. 
b. Baju tidak dimasukkan

Dari hasil observasi peneliti didapatkan ada siswa-siswa laki-laki yang melanggar aturan sekolah dengan tidak memasukkan baju seragam sekolahnya. Padahal aturan yang ada di sekolah tersebut mewajibkan seluruh siswa agar seragam yang mereka pakai bajunya agar tidak dikeluarkan. Tetapi dari hasil observasi peneliti di dalam masing-masing kelas sedikitnya ada 2 orang siswa yang tidak mematuhi peraturan tersebut, yaitu mengeluarkan baju di lingkungan sekolah bahkan pada saat pembelajaran berlangsung. Dari pihak guru PAI pun berdasarkan pengamatan kami sudah ada teguran dan perintah agar mereka segera memasukkan seragamnya, dan siswa-siswa tersebut ketika diperingatkan oleh guru untuk segera memasukkan baju seragamnya langsung mematuhi.

Bentuk perilaku negatif ini memang terlihat kecil tapi meskipun kecil harus segera untuk diselesaikan. Karena permasalahan yang besar terjadi dari permasalahan yang terkecil dulu. Sehingga dalam hal ini tidak ada ruang untuk siswa dalam melakukan bentuk perilaku negatif sekecil apapun. Dan hal ini telah diterapkan di MTs PUI Segeran ini karena ketika ada siswa yang melanggar kedisiplinan dengan mengeluarkan baju seragam maka guru PAI akan segera memberi teguran kepada siswa tersebut. Perilaku tersebut merupakan bentuk upaya dari pihak sekolah untuk menertibkan dan mendisiplinkan siswa.

c. Tidak Mau Mengerjakan Tugas yang diperintahkan Guru

Dari hasil observasi peneliti ketika pada saat jam pelajaran Budi Pekerti, banyak diantara siswa yang tidak mengerjakan tugas dari guru. Ketika itu guru menugaskan kepada siswa untuk menulis ulang apa yang ada di buku, tetapi pada pelaksanaannya banyak siswa yang tidak mengerjakan tugasnya. 4 dari 10 murid laki-laki yang ada di kelas tersebut tidak mengerjakan tugas. Mereka mengabaikan tugas yang diperintahkan oleh gurunya.

Jurnal Pendidikan Agama Islam

IAIN Syekh Nurjati Cirebon 
d. Membuat Gaduh di Kelas saat Pembelajaran

Bentuk perilakunya yaitu seperti menyanyi-nyanyi sehingga menimbulkan suara gaduh, jungkat-jungkit kursi, berlarian dan mondar-mandir dalam kelas, berbicara secara berlebihan pada saat kegiatan belajar mengajar berlangsung, mengobrol dan bergurau.

Hasil observasi peneliti pada saat jam pelajaran Budi Pekerti berlangsung, yaitu dengan suasana mengerjakan tugas dari guru. Ketika itu suasana kelas sangat tidak kondusif hampir semua siswa-siswa di setiap kelas itu mengobrol dan bergurau pada saat jam pelajaran. Suara kegaduhan mengisi seluruh ruangan yang ada di kelas-kelas tersebut, karena perilaku negatif ini dilakukan oleh lebih dari setengah jumlah murid yang ada di masing-masing kelas dan tidak hanya dilakukan oleh murid laki-laki tetapi murid perempuan pun juga turut serta. Hanya sedikit murid yang fokus dan konsentrasi dalam mengerjakan tugas dan hal itu bisa dihitung hanya segelintir orang, yaitu umumnya beberapa murid laki-laki maupun perempuan yang duduk di bangku pertama dan kedua. Bisa dihitung dengan jumlah keseluruhan dari murid yang fokus pada jam pelajaran Budi Pekerti tersebut hanya ada sedikit siswa. Sedangkan murid yang lainnya asyik mengobrol dan bergurau. Dengan demikian dapat dikatakan bahwa sekitar 15-an dari total murid di masing-masing kelas asyik mengobrol dan bergurau pada saat jam pelajaran, dengan data tidak kurang dari 10 siswa laki-laki dan perempuan.

Perilaku tersebut hendaknya mendapatkan perhatian khusus dan penyelesaian yang tepat, upaya yang dapat ditempuh sekolah untuk menghadapi siswa yang berperilaku sosial negatif di sekolah dapat dilakukan dengan memberikan layanan pemecahan masalah yang dihadapi siswa dengan melalui layanan bimbingan, supaya proses belajar mengajar dapat berlangsung optimal. Apabila hal tersebut tidak diatasi maka dalam jangka panjang prestasi siswa akan menurun.

e. Menggambar Nama Geng Motor di Buku ketika Pembelajaran

Perilaku ini juga peniliti dapatkan ketika proses pembelajaran Budi Pekerti, disaat siswa yang lain sedang mengerjakan tugas yang diberikan guru ada salah seorang murid 
laki-laki yang tengah menggambar di buku pelajaran yang ia bawa. Pada awalnya peneliti mengira kalau ia sedang mengerjakan tugas karena ia memang terlihat sibuk menulis. Tapi ternyata setelah peneliti keliling kelas dan melihat aktivitas yang di akukan siswa, peneliti terkejut ternyata siswa tersebut tengah asik menggambar tulisan graviti yang bertuliskan nama salah satu geng motor yang terkenal yaitu XTC. Siswa tersebut duduk di bangku pojok barisan paling depan.

Dari hasil wawancara dengan siswa tersebut siswa kelas 8 yang bernama Reza Mahendra, yakni siswa yang menggambar nama salah satu geng motor pada saat kegiatan pembelajaran berlangsung dan ketika ditanya dari mana ia mengetahui nama geng motor tersebut ia mengatakan tau dari temannya yang mana teman tersebut masih teman sekelasnya yaitu MZA. Kemudian peneliti beranjak untuk mewawancarai MZA untuk menanyakan hal yang sama yaitu dari mana ia mengetahui nama geng motor tersebut. MZA mengatakan bahwa ia mengetahuinya dari teman main yang ada di lingkungan rumahnya.

Perilaku siswa yang satu ini dilakukan tanpa sepengetahuan dari gurunya karena guru mengira siswa tersebut sedang mengerjakan tugas. Namun kegiatan mengerjakan tugas ini guru kurang memperhatikan dan memantau ketika siswa sedang mengerjakan tugasnya sehingga siswa peristiwa ini bisa terjadi.

f. Menyanyi Lagu Persib ketika Pembelajaran

Peneliti menemukan bentuk perilaku tersebut ketika jam pelajaran Qur'an hadits, pada awalnya kelas tersebut sangat disiplin tidak ada yang ribut dan bercanda di dalam kelas ketika pembelajaran berlangsung. Namun ketika guru tersebut meninggalkan kelas sebentar suasana kelas menjadi riuh dan ramai terlebih lagi murid laki-laki yang kemudian langsung menyanyikan lagu Persib Bandung. Namun ketika guru tersebut kembali ke kelas suasana kelas kembali seperti semula tapi masih ada beberapa siswa yang masih melanjutkan menyanyikan lagu tersebut. Lalu guru tersebut ketika mendengar ada siswa yang menyanyikan lagu tersebut langsung meminta siswanya 
untuk menyanyikannya di depan kelas, tapi siswa enggan untuk menuruti perintah dari gurunya dan seketika suasana kelas menjadi sunyi dan kondusif lagi.

g. Membuat dan Memainkan Pesawat dari Kertas ketika Pembelajaran Peneliti melihat aktivitas psikomotor siswa kelas 8 ini sangat aktif sekali sehingga hampir di semua mata pelajaran yang peneliti amati, ketika pembelajaran berlangsung ada beberapa murid laki-laki yang tangannya aktif sekali dalam memainkan kertas untuk dibuat mainan pesawat terbang. Setelah pesawat mainan yang ia buat dari kertas tersebut telah selesai dibuat kemudian langsung memainkannya dengan menerbangkan pesawat tersebut padahal suasana kelas ketika itu sedang ada guru di depan kelas yang sedanng menerangkan materi pembelajaran.

h. Menggunakan Cat/Pewarna Rambut

Ketika pertama kali peneliti tiba di MTs PUI Segeran perhatian peneliti langsung tertuju kepada siswa yang memakai cat rambut di lingkungan sekolah. Karena bukan hanya ada 1 atau 2 orang siswa yang memakai cat rambut melainkan cukup banyak diantara murid MTs PUI yang memakai cat rambut. Cat rambut yang dipakai oleh murid laki-laki tersebut berwarna seragam yakni berwarna Gold atau kuning keemasan. Setelah peneliti memasuki ruangan kelas 8 terlihat dari pengamatan peneliti melihat ada 7 dari 10 murid laki-laki yang ada di kelas 8 tersebut mengenakan cat rambut.

Wawancara dengan siswa yang melakukan pengecatan rambut ini mengatakan bahwa alasan ia menggunakan cat rambut karena mengikuti teman yang lainnya. Ketika ditanya bagaimana respon orang tuanya melihat ia menggunakan cat rambut ia mengatakan bahwa orang tuanya melarang tidak diperbolehkan untuk menggunakan cat rambut tapi dari orang tuanya hanya melarangnya saja.

Berdasarkan hasil temuan penelitian bahwa bentuk perilaku negatif siswa yang ditemukan pada kelas 8 di MTs PUI Segeran ini sangat beragam sekali dan apabila dikaitkan dengan teori menurut Halgin ${ }^{9}$ yang terkait dengan perilaku negatif siswa usia 13-

${ }^{9}$ Richard P. Halgin, Psikologi Abnormal: Perspektif Klinis pada Gangguan Psikologis (Jakarta: Salemba Humanika, 2010), 39.

Jurnal Pendidikan Agama Islam IAIN Syekh Nurjati Cirebon 
15 tahun ini dinamakan dengan ADHD (Attention-deficit/hyperactivity disorder), dimana perilaku ini ditandai dengan sikap perhatiannya anak mudah teralih, diikuti dengan perilakunya yang banyak, banyak gerak dan tidak bisa diam. Selain itu, anak biasanya juga terlihat sangat aktif dalam berbicara, dan perilakunya sering mengganggu orang lain. Ini ditandai dengan kesulitan memperhatikan, aktivitas berlebihan, atau kesulitan mengendalikan perilaku yang tidak sesuai dengan usia. ${ }^{10}$ Gejala hiperaktif ini cenderung hilang seiring bertambahnya usia dan berubah menjadi "kegelisahan batin" pada usia dewasa. ${ }^{11}$

\section{Faktor yang Menyebabkan Perilaku Negatif}

a. Teman Sebaya / Sepermainan

Dalam berinteraksi di dalam lingkungan sekolah siswa banyak berinteraksi dan bersosialisasi dengan temannya. Dari proses interaksi itu pula menghasilkan bentuk perilaku baru yang di lakukan siswa. Hal ini yang menyebabkan faktor teman sebaya yang peneliti lihat dan amati sangat dominan sekali dalam mempengaruhi perilaku negatif siswa. Dalam hasil observasi dan wawancara peneliti dengan siswa dan pihak yang lainnya menemukan bentuk perilaku negatif siswa berasal dari pengaruh teman sebaya. Seperti dalam pembelajaran al-Qur'an Hadits misalnya hasil pengamatan peneliti melihat ada murid laki-laki yang pada awalnya sedang menulis tulisan yang ada di papan tulis kemudian berhenti dan tidak melanjutkan kegiatan menulisnya lagi (tidak menulis) karena diganggu dan diajak bercanda oleh teman yang lainnya dan melihat banyak teman yang lainnya juga yang tidak menulis jadi murid tersebut terpengaruh dan ikut-ikutan tidak menulis juga.

Bentuk perilaku negatif siswa seperti geng motor dan pewarnaan rambut itu juga merupakan hasil dari pengaruh teman sebaya. Hal tersebut berdasarkan hasil wawancara

${ }^{10}$ Sroubek A, Kelly M, Li X. February 2013, "Inattentiveness in Attention-Deficit/Hyperactivity Disorder", dalam Neuroscience Bulletin. 29 (1): 103-10; Caroline SC, ed. Encyclopedia of Cross-Cultural School Psychology. (Berlin, Germany: Springer Science \& Business Media, 2010), 133.

${ }^{11}$ Kooij SJ, Bejerot S, Blackwell A, Caci H, Casas-Brugué M, Carpentier PJ, et al. (September 2010), "European Consensus Statement on Diagnosis and Treatment of Adult ADHD: The European Network Adult ADHD", dalam BMC Psychiatry. 10: 67.

Jurnal Pendidikan Agama Islam

IAIN Syekh Nurjati Cirebon 
peneliti dengan siswa yang bersangkutan yaitu siswa yang bernama RM, siswa yang menggambar nama salah satu geng motor pada saat kegiatan pembelajaran berlangsung dan ketika ditanya dari mana ia mengetahui nama geng motor tersebut ia mengatakan tau dari temannya yang mana teman tersebut masih teman sekelasnya yaitu MZA. Kemudian peneliti beranjak untuk mewawancarai MZA untuk menanyakan hal yang sama yaitu dari mana ia mengetahui nama geng motor tersebut. MZA mengatakan bahwa ia mengetahuinya dari teman main yang ada di lingkungan rumahnya, ia juga menambahkan bahwa hanya mengetahui namanya saja yaitu XTC sebagai nama salah satu geng motor dan tidak mengetahui lebih jelasnya lagi. Demikian juga untuk siswa yang melakukan pewarnaan rambut ketika dilakukan wawancara dengan siswa yang bersangkutan mereka mengatakan alasan menggunakan cat rambut karena megikuti teman-temannya, karena teman-teman yang lainnya banyak yang menggunakan pewarna rambut jadi mereka meniru dan mengikutinya.

b. Guru

Guru sebagai faktor yang menetukan dalam pembentukan bagaimana karakter siswa di dalam ruang lingkup sekolah. Hal ini, karena guru yang mengajar dan mendidik siswanya sehingga bentuk perilaku siswa merupakan hasil dari proses pembelajaran yang dilakukan oleh guru tersebut. Guru berpengaruh dalam faktor yang menyebabkan perilaku negatif siswa. Guru sebagai pendidik dan pengajar yang berinteraksi dengan siswa dalam kegiatan pembelajaran. Oleh karena itu, kegiatan pembelajaran yang dilakukan oleh guru akan menentukan bagaimana perilaku siswa.

c. Ingin menutupi kekurangannya.

Setiap individu mempunyai kekurangan dalam dirinya. Sehingga bentuk individu untuk menyembunyikan kekurangan dalam dirinya berbeda-beda antara satu dengan yang lain nya. Salah satunya yaitu dengan cara berperilaku negatif. Dengan alasan agar kekurangan yang ada dalam diri siswa tersebut tidak mencolok dan tidak diketahui oleh siswa yang lainnya. 
d. Lingkungan sosial siswa

Dalam hal ini adalah dari teman sepermainannya karena siswa di dalam kesehariannya selalu tidak pernah lepas dari interaksi dengan temannya baik di lingkungan sekolah maupun di lingkungan rumah. Anak banyak meluangkan waktu dengan teman sebaya dalam berbagai kegiatan

e. Televisi

Banyak tayangan acara televisi yang tidak mendidik seperti sinetron-sinetron yang sekarang ini lebih anyak mengandung dampak negatifnya dari pada dampak positifnya itu sendiri. Melalui tayangan televisi yang siswa tonton tersebut kemudian siswa meniru dan mencontohnya dalam kehidupan realita mereka. Sehingga banyak dari perilaku negatif siswa itu didapatkan dari tayangan televisi yang mereka tonton. Anak-anak yang belum mempunyai konsep yang benar tentang norma-norma dan nilai-nilai sosial dalam masyarakat anak-anak sering kali menerima mentah-mentah semua tayangan itu. Penerimaan tayangan-tayangan negatif yang ditiru mengakibatkan perilaku negatif pada siswa.

f. Kurangnya pengawasan dari orang tua

Orang tua kurang banyak memantau aktivitas kegiatan yang dilakukan oleh anaknya. Seperti tontonan televisi yang anak tonton misalnya orang tua kurang mengontrol dan mem-filter tontonan mana yang baik dan mana yang tidak baik untuk anak. Orang tua terkesan membiarkan dan memberi kebebasan penuh terhadap tontonan televisi yang anak tonton. Sebagai contoh realitanya banyak tetangga di lingkungan rumah Bapak Nawawi yang orang tuanya tidak memberikan pengawasan terhadap tayangan teleisi yang ditonton oleh anaknya. Orang tuanya membiarkan dan tidak mengawasi, ketidaktahuan orang tua bahwa tontonan televisi juga mempunyai pengaruh yang signifikan terhadap pembentukan perilaku anaknya sehingga banyak orang tua yang tidak memantau dan mengawasi tayangan televisi yang ditonton oleh anaknya.

Perilaku negatif siswa dalam di atas dipengaruhi faktor lingkungan sangat berperan dalam perilaku dan tindakan seseorang, baik faktor lingkungan keluarga maupun Jurnal Pendidikan Agama Islam IAIN Syekh Nurjati Cirebon 
lingkungan masyarakat. Setiap siswa itu mempunyai kepribadian yang berbeda antara yang satu dengan yang lainnya. Sebagaimana dikatakan Gilpin bahwa faktor lingkungan, faktor ekologis, atau faktor lingkungan baik abiotik ataupun biotik mempengaruhi perilaku seseorang. ${ }^{12}$ Tingkah laku seseorang adalah serangkaian tindakan dan tingkah laku yang dibuat dalam hubungannya dengan diri mereka sendiri atau lingkungan mereka ${ }^{13}$ yang mencakup lingkungan di sekitarnya. Ini adalah respon dari individu terhadap berbagai rangsangan atau input, baik internal atau eksternal, sadar atau bawah sadar, terbuka atau rahasia, dan sukarela atau tidak sukarela. ${ }^{14}$

Sementara itu, Hurlock bahwa penyimpangan perilaku pada anak yang berasal dari lingkungan sekitar antara lain pandangan orang tua dan guru terhadap perilaku anak, pola perilaku sosial yang buruk yang berkembang di rumah, lingkungan rumah kurang memberikan model perilaku untuk ditiru, kurang motivasi untuk belajar melakukan penyesuaian sosial, dan anak tidak mendapatkan bimbingan dan bantuan yang cukup dalam proses belajar. ${ }^{15}$

3. Peran Guru Pendidikan Agama Islam dalam Mengatasi Perilaku Negatif Siswa

a. Upaya Preventif (pencegahan)

Dalam mengatasi perilaku negatif peserta didik di MTs PUI Segeran guru Pendidikan Agama Islam melakukan tindakan preventif, dengan bertujuan untuk menghindarkan peserta didik dari banyak bentuk perilaku negatif yang berupa pengaruh dari siswa lainnya. Disamping upaya ini juga dimaksudkan guna menghindarkan peserta didik dari bentuk perilaku negatif lainnya yang bukan tidak mungkin akan mempengaruhi perkembangannya. Karena permasalahan perilaku negatif itu berkembang dari lingkungan sosial.

\footnotetext{
${ }^{12}$ Alan Gilpin, Dictionary of Environment and Sustainable Development (Chichester, New York: Wiley, 1996), 247.

${ }^{13}$ Hemakumara, GPTS. and Rainis, R. 2018, "Spatial Behaviour Modelling of Unauthorised Housing in Colombo," dalam the Asian Journal of Humanities 25(2), Sri Lanka: 91-107.

${ }^{14}$ Minton, Elizabeth A., Lynn R. Khale. 2014. Belief Systems, Religion, and Behavioral Economics. (New York: Business Expert Press LLC, 2014), 137.

${ }^{15}$ Hurlock, op cit, h. 39.

Jurnal Pendidikan Agama Islam IAIN Syekh Nurjati Cirebon 
Oleh sebab itu sebelum seluruhnya mempengaruhi perkembangan mental peserta didik, guru Pandidikan Agama Islam di MTs PUI Segeran melakukan langkah-langkah preventif untuk mencegahnya. Berpijak pada wawancara dengan guru PAI, dia menjelaskan usaha-usaha yang dilakukan untuk mengatasi perilaku negatif siswa-siswa MTs PUI Segeran yaitu:

1) Shalat Berjama'ah sebelum Pulang Sekolah

Aktivitas atau kegiatan rutin yang dilakukan oleh siswa sebelum pulang sekolah yaitu shalat berjama'ah terlebih dahulu. Ketika waktu shalat dzuhur telah tiba maka seluruh siswa di MTs PUI Segeran diperintahkan oleh guru PAI untuk segera pergi ke masjid yang terletak di samping sekolah untuk menunaikan shalat berjama'ah di masjid bersama-sama. Setelah pelaksanaan shalat berjama'ah di masjid selesai kemudian siswa masuk kembali ke kelas untuk melaksanakan kegiatan pembelajaran selanjutnya.

Menurut hasil wawancara dengan guru PAI bahwa kegiatan sholat berjama'ah merupakan suatu kegiatan untuk membiasakan perilaku atau karakter yang baik kepada siswa. Melalui program kegiatan ini diharapkan bisa membuat siswa memiliki akhlak dan kepribadian yang baik.

Kegiatan sholat berjama'ah ini memiliki banyak dampak positif untuk perkembangan perilaku dan moral siswa yang baik. Terutama dalam menanamkan nilai agama kepada siswa yang mana perilaku yang sesuai dengan syariat agama ini sangat baik sekali dimiliki oleh siswa dan di terapkan dalam kehidupan sehari-hari. Dengan di lakukan shalat berjama'ah di sekolah ini siswa diharapkan terbiasa pula melakukan shalat berjama'ah di lingkungan rumahnya.

2) Menyelenggarakan kegiatan Peringatan Hari Besar Islam (PHBI).

3) Menyelenggarakan kegiatan pesantren Ramadhan.

4) Proses keteladanan yang dilakukan guru PAI untuk mengatasi tingkahlaku negatif peserta didik yang masih cenderung labil dan senang meniru perilaku orang lain.

5) Memberdayakan organisasi ekstra dengan berbagai macam programnya. 
6) Mentoring yakni melalui pembagian kelompok yang selanjutnya diisi dengan kajian agama Islam. Materi yang diajarkan mencakup dakwah, ibadah, syari'at, fiqh, akidah, dan akhlak.

Sedangkan hasil wawancara dengan guru PAI yang lain mengenai usaha-usaha yang dilakukan untuk mengatasi perilaku negatif peserta didik ialah:

1) Memberikan keteladanan secara nyata

2) Mengingatkan

3) Menasehati

4) Mengajak dialog atau diskusi mengenai persoalannya

5) Setiap seminggu sekali diselenggarakan kajian agama membahas mengenai berbagai permasalahan yang mencakup ibadah, fiqih, akidah, akhlak, dan sebagainya.

Dari sejumlah usaha yang dilakukan oleh guru PAI di MTs PUI Segeran dalam mengatasi perilaku negatif peserta didiknya, kegiatan monitoring, PHBI, dan pesantren Ramadhan adalah program rutin yang telah menjadi agenda penting guru-guru Pendidikan Agama Islam. Kegiatan monitoring diselenggarakan setiap 2 hari sekali dalam satu minggu guna memberikan pemahaman dan pencerahan mengenai agama dan akhlak sehingga ilmu yang didapatkan dalam kegiatan monitoring bisa diterapkan dalam aktivitas sehari-hari.

b. Upaya Represif

Upaya represif ini ditempuh guna menindak pelanggaran norma ataupun aturan yang berlaku. Hal ini sifatnya lebih kepada mendidik bukan hukuman untuk menindas. Dari hasil wawancara dengan guru PAI MTs PUI Segeran bisa difahami bahwa upaya represif yang dilakukan pada umumnya membuat siswa-siswa merasa bersalah dan tidak berniat kembali berperilaku negatif tersebut. Misalnya dengan memberi tugas yang lebih banyak dibandingkan dengan peserta didik yang lain yang mana diharapkan agar mau belajar dan tidak banyak tertinggal dari teman-temannya. Secara garis besar tindakan represif diberikan dalam wujud pemberian peringatan secara tertulis ataupun lisan kepada pelajar dan orang tua, melakukan pengawasan terutama oleh kepala 
sekolah dan pembimbing atau team guru serta menskorsing (melarang bersekolah) untuk sementara atau seterusnya tergantung dari jenis dan kadar pelanggaran peraturan sekolah yang sudah ditentukan. Umumnya hukuman yang pertama kali ialah teguran lisan dan selanjutnya hukuman yang sifatnya mendidik tidak menindas.

c. Upaya Kuratif

Usaha guru Pendidikan Agama Islam di MTs PUI Segeran dalam mengatasi perilaku negatif siswa yang bersifat penyembuhan (kuratif) dilakukan dengan cara melakukan pendekatan kepada peserta didik yang bermasalah dan diharapkan bisa berjalan efektif dalam menangani perilaku negatif peserta didik. Usaha kuratif guru Pendidikan Agama Islam di MTs PUI Segeran dalam mengatasi perilaku negatif peserta didik bersifat umum artinya dari hasil wawancara dengan ketiga guru Pendidikan Agama Islam didapatkan respon yang hampir sama dalam mengatasi peserta didik yang bermasalah. Langkah-langkah yang ditempuh oleh guru Pendidikan Agama Islam adalah langkah-langkah yang telah seharusnya yang dilakukan oleh seorang guru dalam mengatasi peserta didiknya yang bermasalah. Sejumlah langkah yang dilakukan oleh guru Pendidikan Agama Islam di MTs PUI Segeran dilandaskan kepada jenis perilaku negatif dan faktor penyebabnya, yaitu:

1) Langkah tindakan secara umum yang dilakukan guru Pendidikan Agama Islam di MTs PUI Segeran dalam menangani perilaku negatif peserta didik:

a) Menegur dan menasihati kepada peserta didik yang bermasalah dan memakai pendekatan keagamaan.

b) Memberi perhatian khusus pada peserta didik yang bermasalah yang dilakukan dengan wajar agar tidak menimbulkan kecemburuan sosial.

c) Menghubungi orang tua atau wali siswa mengenai perilaku negatif putra-putrinya agar mereka mengetahui perkembangannya.

2) Langkah penanganan secara khusus guru Pendidikan Agama Islam di MTs PUI Segeran dalam mengatasi permasalahan secara khusus kepada peserta didik yang terlibat kenakalan dilakukan melalui pendekatan khusus, perkasus secara individual. 
Sejumlah hal yang dilakukan guru Pendidikan Agama Islam di MTs PUI Segeran yang berhubungan dengan permasalahan ini yaitu: Untuk mengatasi munculnya perilaku negatif peserta didik karena kurangnya perhatian orang tua langkah yang ditempuh ialah:

a) Memberi bimbingan dengan pengertian kepada peserta didik akan cinta kasih dan kasih sayang orang tua dalam mencari nafkah bagi dirinya.

b) Melakukan pengawasan terhadap tindak dan perilaku peserta didik berupa perhatian khusus yang diberikan kepadanya dengan wajar.

c) Memberikan perhatian kepadanya berupa tanggungjawab kepada dirinya agar pada dirinya lahir rasa percaya diri dan tanggungjawab kepada aktifitas yang dilaksanakan.

Dalam rangka mengatasi perilaku negatif peserta didik disebabkan pengaruh lingkungan hal-hal yang ditempuh ialah:

a) Selalu memberikan pengertian kepada peserta didik mengenai banyak hal yang harus diteladani (ditiru) dan yang perlu dicontoh.

b) Memantau perkembangan peserta didik dan jika terjadi penyimpangan perilaku yang membahayakan untuk sesegera mungkin diatasi.

c) Mengharuskan peserta didik untuk berbuat baik sesuai dengan akidah agama serta dapat berperilaku sesuai dengan tata tertib, norma, dan aturan yang ada di MTs PUI Segeran.

Dari hasil wawancara dengan guru Pendidikan Agama Islam MTs PUI Segeran, usaha kuratif yang dilakukan untuk menangani perilaku negatif peserta didik tentunya juga bekerjasama dengan guru-guru mata pelajaran lain dan terutama dengan guru BP. Menurut guru PAI MTs PUI Segeran saat menangani peserta didik yang telah melampaui batas toleransi, maka peserta didik yang bersangkutan dilimpahkan ke guru BP untuk dijatuhi sanksi dan jika masih saja tetap masih melanggar maka telah menjadi kewenangan Kepala Sekolah untuk dikeluarkan dari sekolah atau diberikan kesempatan kembali agar tidak mengulangi perilaku negatif. 
Begitu pula dengan upaya preventif dan usaha kuratif telah dilakukan seoptimal mungkin, namun jika peserta didik yang bersangkutan tetap saja mengulangi perbuatannya, maka upaya selanjutnya dilakukan yaitu dengan menyerahkan peserta didik yang bersangkutan ke guru BP. Namun jika dalam penanganan guru BP peserta didik yang bersangkutan masih sukar untuk merubah tingkahlakunya, maka upaya akhir diserahkan kepada Kepala Sekolah untuk dijatuhi sanksi dikeluarkan dari sekolah.

Usaha guru Pendidikan Agama Islam MTs PUI Segeran dalam mengatasi persoalan perilaku peserta didik adalah usaha dan tindakan yang memang mesti dilakukan untuk mendidik dan membimbing para siswa. Permasalahan yang dihadapi guru dalam membimbing dan sangat komplek. Karena usia peserta didik yang memasuki masa remaja mengalami penyesuaian diri yang berawal dari adanya tuntutan kebutuhan biologis pada dirinya, serta untuk mendapatkan kesenangan. Jika kebutuhan yang seperti itu terhambat atau tidak terpenuhi, maka terjadilah frustasi, yaitu perasaan kecewa karena terjadinya kegagalan untuk mencapai keinginan. Rasa frustasi itulah yang selanjutnya memunculkan banyak aspek psikologi, contoh sikap berprasangka, permusuhan, benci, iri, dan sebagainya.

Sementara siswa yang tidak dapat melepaskan diri dari perasaan kecewa tersebut akan mengalami ketidakmampuan di dalam melakukan adaptasi dengan lingkungannya. Ketidakmampuan yang seperti itu akhirnya berubah menjadi penyimpangan perilaku/kenakalan. Bagi guru Pendidikan Agama Islam MTs PUI Segeran persoalan tersebut mesti dipahami seutuhnya agar dapat memberikan solusi yang tepat, jika menghadapi banyak perilaku negatif siswanya. Oleh karena itu, persoalan perilaku negatif peserta didik tentunya tidak saja menjadi tanggungjawab guru PAI saja akan tetapi harus ada kerjasama yang simultan dari guru-guru yang lain untuk dapat mengatasi persoalan tersebut. Sehingga cita-cita dan harapan bersama bisa terealisasi. Hal tersebut sebagaimana ditegaskan oleh Brophy bahwa merubah perilaku negatif 
siswa harus melibatkan partisipasi aktif seluruh warga sekolah termasuk kesadaran kuat siswa yang ditumbuhkan oleh guru (Brophy, 1986: 191). ${ }^{16}$

\section{E. Kesimpulan}

1. Bentuk perilaku negatif siswa kelas MTS PUI Segeran Kidul Indramayu diperoleh bentuk perilaku negatif yang beragam diantaranya: menyalakan petasan di dalam kelas, baju seragam yang tidak dimasukkan, tidak mau mengerjakan tugas yang diperintahkan guru, menngobrol dan bergurau dalam pembelajaran, menggambar nama geng motor di buku, menyanyikan lagu persib, membuat dan memainkan pesawat dari kertas. Yang mana hal perilaku negatif tersebut berkaitan dengan pelaksanakan tugas perilaku pada masa perkembangannya. Apabila anak dapat melaksanakan tugas perilaku pada masa perkembangannya dengan baik, anak tersebut dikatakan berperilaku normal. Masalah muncul apabila anak berperilaku tidak sesuai dengan tugas perkembangannya.

2. Faktor yang menyebabkan siswa dalam berperilaku negatif siswa dapat diklasifikasikan ke dalam 2 jenis faktor yaitu faktor internal dan eksternal. (1) faktor internal yang meliputi rasa malas, ingin diperhatikan, ingin menutupi kekurangannya. (2) faktor eksternal yang meliputi lingkungan keluarga tayangan TV, lingkungan sekolah, dan lingkungan masyarakat yang kurang mendukung.

3. Sosok guru sebagai pendidik memegang peran yang sangat vital sekali dalam pembentukkan dan pengendalian perilaku siswa berdasarkan observasi yang peneliti temukan. Gejala perilaku bermasalah pada siswa di sekolah sangat beragam karena pada dasarnya setiap anak memiliki masalah-masalah emosional dan penyesuaian sosial yang berbeda satu dengan yang lainnya. Oleh sebab itu dalam hal ini tugas guru tidak hanya terbatas pada penyampaian informasi pembelajaran kepada peserta didik saja tetapi juga menyangkut penanaman dan pembentukan perilaku yang ada di dalam diri siswa siswa.

4. Usaha guru Pendidikan Agama Islam MTs PUI Segeran dalam mengatasi perilaku negatif siswa, bersifat preventif, yakni: salat berjamaah, PHBI, pesantren Ramadhan, keteladanan

\footnotetext{
${ }^{16}$ Brophy, J. 1986. “Classroom Management Techniques," dalam Education and Urban Society 18/2. 182-194. Jurnal Pendidikan Agama Islam IAIN Syekh Nurjati Cirebon
} 
yang dilakukan guru PAI, memberdayakan organisasi ekstra, mentoring, mengingatkan, menasehati, mengajak dialog, kajian agama seminggu sekali. Langkah represif adalah: memberikan hukuman yang lebih ke arah mendidik bukan menindas, memberikan tugas yang lebih banyak dibandingkan peserta didik yang lain. Bersifat kuratif yaitu: (1) Langkah penanganan secara umum yaitu: (a) Nasehat dan teguran dengan pendekatan keagamaan. (b) Memberikan perhatian khusus secara wajar kepada peserta didik yang bermasalah. (c) Melakukan kerjasama dengan orang tua peserta didik yang bermasalah dalam mengatasi perilaku negatif anaknya. (2) Upaya penanganan secara khusus untuk peserta didik yang bermasalah dengan cara melakukan pendekatan kasus perkasus secara individual.

\section{Daftar Pustaka}

Brophy, J. 1986. "Classroom Management Techniques," dalam Education and Urban Society 18/2. 182-194.

Caroline SC, ed. 2010. Encyclopedia of Cross-Cultural School Psychology. Berlin, Germany: Springer Science \& Business Media.

Daradjat, Zakiyah. 1995. Remaja Harapan dan Tantangan. Jakarta: Ruhama

Darwis, Abu. 2006. Perilaku Menyimpang Murid SD. Jakarta: Departemen Pendidikan Nasional Direktorat Jendral Pendidikan Tinggi Direktorat Ketenagaan.

Gerungan, W.A, 1978. Psikologi Sosial. Bandung: PT. al-Maarif.

Gilpin, Alan, 1996. Dictionary of environment and sustainable development, Chichester ; New York : Wiley

Halgin, Richard P. 2010. Psikologi Abnormal: Perspektif Klinis pada Gangguan Psikologis. Jakarta: Salemba Humanika.

Hemakumara, GPTS. and Rainis, R. 2018. "Spatial Behaviour Modelling of Unauthorised Housing in Colombo," dalam the Asian Journal of Humanities 25(2), Sri Lanka: 91-107.

Hurlock, Elizabeth. B. 2004. Perkembangan Anak Jilid 1. Jakarta: Erlangga

Kooij SJ, Bejerot S, Blackwell A, Caci H, Casas-Brugué M, Carpentier PJ, et al. (September 2010). "European Consensus Statement on Diagnosis and Treatment of Adult ADHD: The European Network Adult ADHD", dalam BMC Psychiatry. 10: 67.

LN, Syamsu Yusuf. 2009. Psikologi Perkembangan Anak dan Remaja. Bandung: Remaja Rosdakarya.

Jurnal Pendidikan Agama Islam

IAIN Syekh Nurjati Cirebon 
Marsudi, Saring. 2003. Layanan Bimbingan Belajar di Sekolah. Surakarta: Muhammadiyah University Press.

Minton, Elizabeth A., Lynn R. Khale. 2014. Belief Systems, Religion, and Behavioral Economics. New York: Business Expert Press LLC.

Sroubek A, Kelly M, Li X. February 2013. "Inattentiveness in Attention-Deficit/Hyperactivity Disorder”, dalam Neuroscience Bulletin. 29 (1): 103-10.

Gilpin, A. 1996. Dictionary of Environment and Sustainable Development. Hoboken, New Jersey, United States: John Wiley and Sons. 